\title{
Nitrogen and Carbon Characteristics of Sludges from Formic Acid and Sodium Hydroxide Pulping of Kenaf Stem
}

\author{
Chukwudebelu JA ${ }^{1 *}$ and Agunwamba $\mathrm{JC}^{2}$ \\ ${ }^{1}$ Department of Chemical, Fibre and Environmental Technology, Federal Institute of Industrial Research, Nigeria \\ ${ }^{2}$ Department of Civil Engineering, University of Nigeria, Nigeria
}

Submission: November 24, 2020; Published: January 04, 2021

*Corresponding author: Chukwudebelu JA, Department of Chemical, Fibre and Environmental Technology, Federal Institute of Industrial Research, Oshodi, Nigeria

Abstract

Sludge is produced during paper manufacturing. In this study, kenaf stem was pulped with formic acid and sodium hydroxide at $20 \%, 60 \%$ and $90 \%$ concentrations for a cooking period of 1,2 and $3 \mathrm{~h}$ at $960 \mathrm{C}$ under atmospheric pressure. The effluent from the pulping processes was filtered to get the sludge. The sludge was analysed for carbon and nitrogen. The sludge content from $20 \%$ pulping has nitrogen and carbon from sodium hydroxide, sludge from $60 \%$ pulping has carbon and nitrogen from both chemicals with more nitrogen while $90 \%$ pulping has more carbon. Considering the pulped stem, it showed under pulped, normal and over pulped with respect to $20 \%, 60 \%$ and $90 \%$. Therefore, looking at the normal pulp at $60 \%$ concentration with the two chemicals, formic acid has moderate values of carbon and nitrogen compare to sodium hydroxide that showed high nitrogen content. Formic acid pulping is considered here because it can easily be recovered after pulping and the sludge used as manure.

Keywords: Kenaf; Sludge; Formic acid; Sodium hydroxide; Nitrogen; Carbon; Pulp

\section{Introduction}

The paper mill and pulp industry produce enormous quantities of paper and pulp products each year. It is the sixth largest polluting industry after the oil, cement, leather, textile, and steel industries, and many environmental contaminants are associated with the discharge of paper and pulp mill sludge [1]. Paper manufacturing is a complex industry involving multiple processes where different products are produced and large quantities of waste of primary, biological or de-inking origin are generated, waste water treatment sludge, primary sludge, and secondary sludge among them $[2,3]$.

Pulp and paper mill production is growing every year worldwide. As a consequence, the amount of generated waste is increasing, along with increasing concern [4].

Sludge is the final solid waste recovered from the wastewater treatment process in pulp and paper mills. Sludge discharged from paper mills is divided into four categories:

a) primary sludge (PS), which comes from the production of virgin wood fiber;

b) de-inking paper sludge (DPS), which comes from the process of removing inks from recycled paper; c) secondary sludge (SS; activated sludge), which comes from the secondary wastewater treatment system; and

d) combined primary and secondary sludge [5].

The sludge composition generally comprises organic matter, nitrogen and phosphorus, which can be used as macronutrient fertilizers in agriculture [6]. Nitrogen is important for growth of plant, its food processing and creation of chlorophyll. Carbon is the main part of soil organic matter and it aids soil to have waterretention capacity, form and fertility.

The sources of solids in a treatment plant vary according to the type of plant and its method of operation [7,8]. The amount and chemical composition, as well as the geotechnical properties of paper mill sludge depend on the paper grade being manufactured, specific fresh water consumption, the wastewater cleaning technique applied and the type of raw materials (e.g. wood, fillers). Thus, the chemical composition of paper mill sludge produced by one mill is often significantly different from that of another $[9,10]$.

Many parameters have been introduced and tests developed to measure specific properties of sludge in relation to particular 
methods of treatment. Conventional sludge characteristics can be grouped in physical, chemical and biological parameters. Physical parameters give general information on sludge processability and handlability. Chemical parameters are relevant to the presence of nutrients and toxic/dangerous compounds, so they become necessary in the case of utilization in agriculture. Biological parameters give information on microbial activity and organic matter/pathogens presence, thus allowing the safety of use to be evaluated [11].

Natural and anthropogenic environmental changes greatly influence the behaviour of metallic pollutants in sludge, as the form in which they occur may be change. Such external factors can include $\mathrm{pH}$, temperature, the redox potential, organic matter decomposition, leaching, ion exchange processes and microbiological activity [12].

The pulp and paper industry consumes enormous amounts of water and natural resources and is also one of the largest effluents generators. Before the 1970s, wastewaters from the pulp and paper mills were normally discharged directly to the rivers or lakes, without any treatment or even a rough primary treatment. The high organic loads and solid content in the effluents affected the aquatic ecosystem in several ways such as localized damage to the benthic community, oxygen depletion in large areas and numerous changes in fish reproduction and physiology [13].

This study sets out to find out the effects of chemical, concentration and time interactions under laboratory conditions on the quality of sludge considering nitrogen and carbon from two chemical pulping processes.

\section{Materials and Methods}

Kenaf stem was pulped with formic acid and sodium hydroxide at 20,60 and $90 \%$ concentrations for a cooking time of 1,2 and $3 \mathrm{~h}$ at $95^{\circ} \mathrm{C}$ under atmospheric pressure. At the end of each period, the sample was filtered with a fine mesh sieve of size $0.027 \mathrm{~mm}$ to get effluent and the effluent was filtered with a filter paper to get the sludge used in the analyses. The sludge samples were then air-dried and screened to remove other contaminating materials. The screened raw materials were ground and placed in an airtight container to balance the moisture content and then used for chemical analysis. The tests were carried out in triplicate and each value is an average of three samples.

\section{Determination of nitrogen content}

Nitrogen content of the sample was determined by using Kjedahl technique [14]. The method involves digestion of samples, distillation of digests and titration of distillate.

$$
\text { Calculation : } \% N=\frac{T \times 14.01 \times \text { Molarity of } \mathrm{HCl}(0.1) \times 100 \times 10}{\text { Weight of sample taken }(2 \mathrm{~g}) \times 1000}
$$

Where $\mathrm{T}=($ sample titre - blank titre $)$

\section{Determination of carbon content}

Colorimetric method of [15] was used to calculate the total carbon (Figure 1).
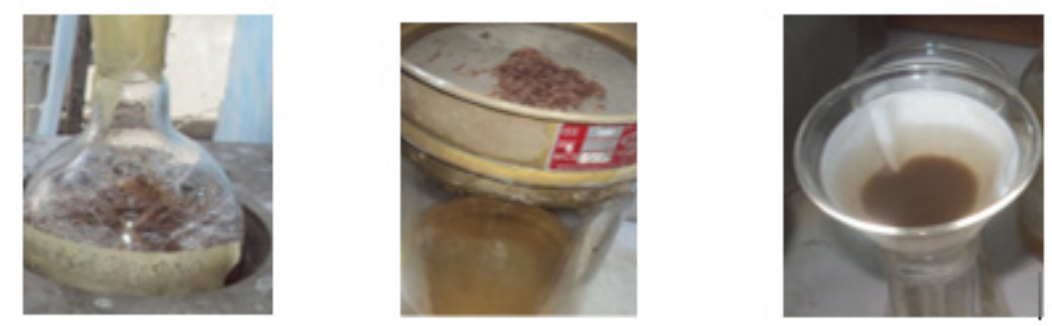

\section{Pulping Filtration for effluent Filtration for sludge}

Figure 1: Processes used in getting sludge.

\section{Results and Discussion}

Table 1 presents the values of carbon and nitrogen from sludge obtained from pulping kenaf stem with $20 \%$ concentration of FA and $\mathrm{NaOH}$. The sludge from formic acid pulping with $20 \%$ formic acid at three-hour intervals did not show any presence of carbon and nitrogen. Carbon and nitrogen were detected in the sludge from sodium hydroxide pulping at three-hour intervals in a decreasing concentration. The highest concentrations of carbon $(0.17 \%)$ and nitrogen $(1.67 \%)$ were obtained after 1 -hour pulping while the lowest $(0.07 \& 0.63)$ were after two hours pulping. The increase of carbon content after three hours pulping may be as a result of esterification reaction as reported by [16]. 
Table 1: Sludge from pulping with $20 \% \mathrm{FA}$ and $\mathrm{NaOH}$.

\begin{tabular}{|c|c|c|c|}
\hline \multirow{2}{*}{ Time(Hrs) } & $\begin{array}{c}\text { Chemicals/ } \\
\text { Parameters }\end{array}$ & Carbon (\%) & Nitrogen (\%) \\
\hline \multirow{2}{*}{1} & $\mathrm{FA}$ & 0 & 0 \\
\cline { 2 - 4 } & $\mathrm{NaOH}$ & 0.17 & 1.67 \\
\hline \multirow{2}{*}{2} & $\mathrm{FA}$ & 0 & 0 \\
\cline { 2 - 4 } & $\mathrm{NaOH}$ & 0.07 & 0.63 \\
\hline \multirow{2}{*}{3} & $\mathrm{FA}$ & 0 & 0 \\
\cline { 2 - 4 } & $\mathrm{NaOH}$ & 0.11 & 0.67 \\
\hline
\end{tabular}

Nitrogen content of sludge from $\mathrm{NaOH}$ has close values and showed a little increase from 2 hours $(0.63 \%)$ to three hours $(0.67 \%)$. According to [17], the little increase in nitrogen may be due basic character of amine and hydrogen as triethylamine which took part in the reaction.

Table 2 shows the values of carbon and nitrogen in the sludge from pulping kenaf stem at $60 \%$ formic acid and sodium hydroxide. Carbon was detected throughout the 3-hour pulping with $60 \%$ formic acid, but the value did not follow a particular pattern because the highest value (8.7\%) was obtained at 2 hour pulping followed by 3 hour (3.57\%), while the lowest was at 1 hour $(1.77 \%)$. With sodium hydroxide, carbon did not show a significance difference but only a minimal increase $(0.03 \%)$ at 3-hour pulping. Nitrogen content in the sludge from formic acid is lower than that from sodium hydroxide which shows high percentage of nitrogen. The nitrogen values increased (18.1 -39.77) with time during sodium hydroxide pulping which may be due to the presence of triethylamine as reported by [17], while nitrogen in formic acid pulping sludge shows low values with minimal variations throughout the pulping period with the highest $(0.29 \%)$ recorded after 2 hours pulping.

Table 2: Sludge from pulping with $60 \% \mathrm{FA}$ and $\mathrm{NaOH}$.

\begin{tabular}{|c|c|c|c|}
\hline \multirow{2}{*}{ Time(Hrs) } & $\begin{array}{c}\text { Chemicals/ } \\
\text { Parameters }\end{array}$ & Carbon(\%) & Nitrogen(\%) \\
\hline \multirow{2}{*}{1} & $\mathrm{FA}$ & 1.77 & 0.25 \\
\cline { 2 - 4 } & $\mathrm{NaOH}$ & 0.02 & 18.1 \\
\hline \multirow{2}{*}{2} & $\mathrm{FA}$ & 8.7 & 0.29 \\
\cline { 2 - 4 } & $\mathrm{NaOH}$ & 0.02 & 29.4 \\
\hline \multirow{2}{*}{3} & $\mathrm{FA}$ & 3.57 & 0.13 \\
\cline { 2 - 4 } & $\mathrm{NaOH}$ & 0.03 & 39.77 \\
\hline
\end{tabular}

Table 3 reported the values of nitrogen and carbon contained in the sludge obtained during pulping of kenaf stem with $90 \%$ formic acid and sodium hydroxide at three-hour period. The values of carbon from both chemicals during the three-hour pulping were higher than those obtained from $20 \%$ and $60 \%$ pulping with sludge from formic acid pulping having the highest values (3.37-8.73\%). The highest carbon $(8.73 \%)$ was obtained after 3-hour pulping with formic acid while sodium hydroxide gave highest value (4.3\%) after 1-hour pulping. Nitrogen content from both formic acid and sodium hydroxide pulping have close values $(0.13-0.28)$ with formic acid showing a little higher value. This result has a little similarity with [18] that reported $0.9 \%$ for nitrogen Table 4.

Table 3: Sludge from pulping with $90 \% \mathrm{FA}$ and $\mathrm{NaOH}$.

\begin{tabular}{|c|c|c|c|}
\hline \multirow{2}{*}{ Time(Hrs) } & $\begin{array}{c}\text { Chemicals/ } \\
\text { Parameters }\end{array}$ & Carbon (\%) & Nitrogen (\%) \\
\hline \multirow{2}{*}{1} & FA & 5.2 & 0.18 \\
\cline { 2 - 4 } & $\mathrm{NaOH}$ & 4.3 & 0.14 \\
\hline \multirow{2}{*}{2} & $\mathrm{FA}$ & 3.37 & 0.28 \\
\cline { 2 - 4 } & $\mathrm{NaOH}$ & 2.3 & 0.23 \\
\hline \multirow{2}{*}{3} & $\mathrm{FA}$ & 8.73 & 0.22 \\
\cline { 2 - 4 } & $\mathrm{NaOH}$ & 1.23 & 0.13 \\
\hline
\end{tabular}

*Each value is an average of three samples.

(Source: Author's lab work).

Table 4: Mean and SE of Sludge over the concentration, time and chemical factors for pulping.

\begin{tabular}{|c|c|c|c|c|}
\hline \multirow{2}{*}{$\begin{array}{l}\text { Concentra- } \\
\text { tion }\end{array}$} & \multirow{2}{*}{ Time } & \multirow{2}{*}{ Chemical } & $\begin{array}{c}\text { Nitrogen } \\
\text { (\%) }\end{array}$ & Carbon (\%) \\
\hline & & & Mean + SE & Mean + SE \\
\hline \multirow{6}{*}{$20 \%$} & \multirow{2}{*}{1 Hour } & $\mathrm{NaOH}$ & $1.67+1.01$ & $0.17+0.06$ \\
\hline & & Formic Acid & & \\
\hline & \multirow{2}{*}{2 Hours } & $\mathrm{NaOH}$ & $0.63+1.01$ & $0.07+0.06$ \\
\hline & & Formic Acid & & \\
\hline & \multirow{2}{*}{3 Hours } & $\mathrm{NaOH}$ & $0.67+1.01$ & $0.11+0.06$ \\
\hline & & Formic Acid & & \\
\hline \multirow{6}{*}{$60 \%$} & \multirow{2}{*}{1 Hour } & $\mathrm{NaOH}$ & & $0.02+0.06$ \\
\hline & & Formic Acid & $0.25+1.01$ & $1.77+0.06$ \\
\hline & \multirow{2}{*}{2 Hours } & $\mathrm{NaOH}$ & $29.4+1.01$ & $0.02+0.06$ \\
\hline & & Formic Acid & $0.29+1.01$ & $8.7+0.06$ \\
\hline & \multirow{2}{*}{3 Hours } & $\mathrm{NaOH}$ & $\begin{array}{c}39.77+ \\
1.01\end{array}$ & $0.03+0.06$ \\
\hline & & Formic Acid & $0.13+1.01$ & $3.57+0.06$ \\
\hline \multirow{6}{*}{$90 \%$} & \multirow{2}{*}{1 Hour } & $\mathrm{NaOH}$ & $0.14+1.01$ & $4.3+0.06$ \\
\hline & & Formic Acid & $0.18+1.01$ & $5.2+0.06$ \\
\hline & \multirow{2}{*}{2 Hours } & $\mathrm{NaOH}$ & $0.23+1.01$ & $2.3+0.06$ \\
\hline & & Formic Acid & $0.28+1.01$ & $3.37+0.06$ \\
\hline & \multirow{2}{*}{3 Hours } & $\mathrm{NaOH}$ & $0.13+1.01$ & $1.23+0.06$ \\
\hline & & Formic Acid & $0.22+1.01$ & $8.73+0.06$ \\
\hline
\end{tabular}


The Table 5 \& above shows Anova table that all the factors and interactions were significant $(\mathrm{p}<0.05)$ except time.

Table 5: Mean and SE of Nitrogen (\%) Sludge over the concentration, time and chemicals for pulping.

\begin{tabular}{|c|c|c|c|}
\hline Concentration & Time & Chemical & Mean + SE \\
\hline \multirow{6}{*}{$20 \%{ }^{\mathrm{a}}$} & \multirow{2}{*}{1 Hour } & $\mathrm{NaOH}$ & $1.67+1.01$ \\
\hline & & Formic Acid & \\
\hline & \multirow{2}{*}{2 Hours } & $\mathrm{NaOH}$ & $0.63+1.01$ \\
\hline & & Formic Acid & \\
\hline & \multirow{2}{*}{3 Hours } & $\mathrm{NaOH}$ & $0.67+1.01$ \\
\hline & & Formic Acid & \\
\hline \multirow{6}{*}{$60 \%{ }^{\mathrm{b}}$} & \multirow{2}{*}{1 Hour } & $\mathrm{NaOH}$ & \\
\hline & & Formic Acid & $0.25+1.01$ \\
\hline & \multirow{2}{*}{2 Hours } & $\mathrm{NaOH}$ & $29.4+1.01^{\mathrm{a}}$ \\
\hline & & Formic Acid & $0.29+1.01^{b}$ \\
\hline & \multirow{2}{*}{3 Hours } & $\mathrm{NaOH}$ & $39.77+1.01^{a}$ \\
\hline & & Formic Acid & $0.13+1.01 b$ \\
\hline \multirow{6}{*}{$90 \%{ }^{a}$} & \multirow{2}{*}{1 Hour } & $\mathrm{NaOH}$ & $0.14+1.01^{a}$ \\
\hline & & Formic Acid & $0.18+1.01^{\mathrm{a}}$ \\
\hline & \multirow{2}{*}{2 Hours } & $\mathrm{NaOH}$ & $0.23+1.01 a$ \\
\hline & & Formic Acid & $0.28+1.01^{\mathrm{a}}$ \\
\hline & \multirow{2}{*}{3 Hours } & $\mathrm{NaOH}$ & $0.13+1.01^{\mathrm{a}}$ \\
\hline & & Formic Acid & $0.22+1.01^{a}$ \\
\hline
\end{tabular}

\begin{tabular}{|c|c|c|c|c|c|}
\hline Source & $\begin{array}{l}\text { Sum of } \\
\text { Squares }\end{array}$ & df & $\begin{array}{l}\text { Mean } \\
\text { Square }\end{array}$ & $\mathbf{F}$ & Sig. \\
\hline Conc & 2777.239 & 2 & 1388.619 & 456.523 & 0 \\
\hline Time & 15.019 & 2 & 7.509 & 2.469 & 0.103 \\
\hline Chemical & 1744.485 & 1 & 1744.485 & 573.518 & 0 \\
\hline conc* Time & 67.507 & 4 & 16.877 & 5.548 & 0.002 \\
\hline Conc * chemical & 1779.17 & 1 & 1779.17 & 584.921 & 0 \\
\hline Time * chemical & 41.24 & 2 & 20.62 & 6.779 & 0.004 \\
\hline $\begin{array}{l}\text { Conc } * \text { Time } * \\
\text { chemical }\end{array}$ & 41.87 & 1 & 41.87 & 13.765 & 0.001 \\
\hline Error & 85.168 & 28 & 3.042 & & \\
\hline Corrected Total & 6261.417 & 41 & & & \\
\hline
\end{tabular}

\section{ANOVA Table}

$\mathrm{R}$ Squared $=.986$ (Adjusted R Squared $=.980)$.

The Anova table above shows that all the factors and interactions were significant $(p<0.05)$ except time.

Table 6 \& above shows Anova table that both all the factors and interactions were significant $(\mathrm{p}<0.05)$.
Table 6: Mean and SE of Carbon (\%) Sludge over the concentration, time and chemicals for pulping.

\begin{tabular}{|c|c|c|c|}
\hline Concentration & Time & Chemical & Mean + SE \\
\hline \multirow{6}{*}{$20 \%{ }^{a}$} & \multirow{2}{*}{1 Hour } & $\mathrm{NaOH}$ & $0.17+0.06$ \\
\hline & & Formic Acid & \\
\hline & \multirow{2}{*}{2 Hours } & $\mathrm{NaOH}$ & $0.07+0.06$ \\
\hline & & Formic Acid & \\
\hline & \multirow{2}{*}{3 Hours } & $\mathrm{NaOH}$ & $0.11+0.06$ \\
\hline & & Formic Acid & \\
\hline \multirow{6}{*}{$60 \%{ }^{\mathrm{b}}$} & \multirow{2}{*}{1 Hour } & $\mathrm{NaOH}$ & $0.02+0.06^{z}$ \\
\hline & & Formic Acid & $1.77+0.06^{b}$ \\
\hline & \multirow{2}{*}{2 Hours } & $\mathrm{NaOH}$ & $0.02+0.06^{a}$ \\
\hline & & Formic Acid & $8.7+0.06^{b}$ \\
\hline & \multirow{2}{*}{3 Hours } & $\mathrm{NaOH}$ & $0.03+0.06^{\mathrm{a}}$ \\
\hline & & Formic Acid & $3.57+0.06^{\mathrm{b}}$ \\
\hline \multirow{6}{*}{$90 \%{ }^{\mathrm{c}}$} & \multirow{2}{*}{1 Hour } & $\mathrm{NaOH}$ & $4.3+0.06^{\mathrm{a}}$ \\
\hline & & Formic Acid & $5.2+0.06^{b}$ \\
\hline & \multirow{2}{*}{2 Hours } & $\mathrm{NaOH}$ & $2.3+0.06^{a}$ \\
\hline & & Formic Acid & $3.37+0.06^{b}$ \\
\hline & \multirow{2}{*}{3 Hours } & $\mathrm{NaOH}$ & $1.23+0.06^{\mathrm{a}}$ \\
\hline & & Formic Acid & $8.73+0.06^{b}$ \\
\hline
\end{tabular}

\begin{tabular}{|c|c|c|c|c|c|}
\hline Source & $\begin{array}{c}\text { Sum of } \\
\text { Squares }\end{array}$ & df & $\begin{array}{c}\text { Mean } \\
\text { Square }\end{array}$ & F & Sig. \\
\hline Conc & 39.047 & 2 & 19.523 & 1993.978 & 0 \\
\hline Timehr & 6.27 & 2 & 3.135 & 320.186 & 0 \\
\hline Chem & 137.358 & 1 & 137.358 & 14028.89 & 0 \\
\hline conc* Time & 53.824 & 4 & 13.456 & 1374.305 & 0 \\
\hline conc* chem & 5.078 & 1 & 5.078 & 518.584 & 0 \\
\hline Time* chem & 30.617 & 2 & 15.308 & 1563.487 & 0 \\
\hline $\begin{array}{c}\text { conc* Time } \\
\text { chem }\end{array}$ & 50.736 & 2 & 25.368 & 2590.91 & 0 \\
\hline Error & 0.294 & 30 & 0.01 & & \\
\hline $\begin{array}{c}\text { Corrected } \\
\text { Total }\end{array}$ & 381.458 & 44 & & & \\
\hline
\end{tabular}

\section{ANOVA Table}

$\mathrm{R}$ Squared $=.999$ (Adjusted R Squared $=$.999).

Table above shows that both all the factors and interactions were significant $(p<0.05)$.

\section{Conclusion}

The sludge content from $20 \%$ pulping has nitrogen and carbon from sodium hydroxide, sludge from $60 \%$ pulping has carbon and nitrogen from both chemicals with more nitrogen while $90 \%$ pulping has more carbon. Considering the pulped stem, it showed under pulped, normal and over pulped with 
respect to $20 \%, 60 \%$ and $90 \%$. Therefore, looking at the normal pulp at $60 \%$ concentration with the two chemicals, formic acid has moderate values of carbon and nitrogen compare to sodium hydroxide that showed high nitrogen content. Formic acid pulping is considered here because it can easily be recovered after pulping and the sludge used as manure. However, further research is recommended with more focus on other sludge parameters.

\section{Acknowledgement}

The support from the Federal Institute of Industrial Research, Oshodi, Lagos, Nigeria and University of Nigeria, Nsukka, during this work is well appreciated.

\section{References}

1. Ali M, Sreekrishnan TR (2001) Aquatic toxicity from pulp and paper mill effluents: A review. Adv Env Res 5(2): 175-196.

2. Monte M, Fuente E, Blanco A, Negro C (2009) Waste Management from pulp and Paper Production in the European Union. Waste Manag 29(1): 293-308.

3. Bajpai P (2015) Management of pulp and Paper Mill Waste. Springer International Publishing. Switzerland.

4. Simao L, Hotza D, Raupp Pereira F, Labrincha JA, Montedo ORK (2018) Wastes from pulp and paper mills - a review of generation and recycling alternatives. Cerâmica 64(371): 443-453.

5. Geng S, Zhang Y, James D (2007) Characteristics of Paper Mill Sludge and its Utilization for the Manufacture of Medium Density Fiberboard. Wood and Fiber Science 39(2): 345-351.

6. Ribeiro P, Albuquerque A, Quinta Nova L, Cavaleiro V (2010) Recycling pulp mill sludge to improve soil fertility using GIS tools. Resour Conserv Recycl 54: 1303-1311.

7. Metcalf, Eddy (2003) Wastewater Engineering-Treatment and Reuse. In: Tchobanoglous G, Burton FL, Stensel HD (Eds.), ( $4^{\text {th }}$ edn), McGrow Hill, New York, USA.
8. Tay J, Yang P, Zhuang W, Tay S, Pan Z (2007) Reactor performance and membrane filtration in aerobic granular sludge membrane bioreactor. Journal of Membrane Science 304(1-2): 24-32.

9. Jackson M, Line M (1997) Organic composition of a pulp and paper mill sludge determined by FTIR, ${ }^{13} \mathrm{C}$ CP MAS NMR, and chemical extraction techniques. J Agric Food Chem 45(6): 2354-2358.

10. Battaglia A, Calace N, Nardi E, Petronio B, Pietroletti M (2003) Paper mill sludge - soil mixture: kinetic and thermodynamic tests of cadmium and lead sorption capability. Microchem J 75(2): 97-102.

11.Yan S, Bala S, Tyagi, R, Surampalli R (2009) Wastewater Sludge Characteristics Chapter 2.

12. Kazi T, Jamali M, Kazi G, Arain M, Afridi H, et al. (2005) Evaluating the mobility of toxic metals in untreated industrial wastewater sludge using a BCR sequential extraction procedure and a leaching test. Anal Bioanal Chem 383(2): 297-304.

13. María N (2017) Pulp Mill Wastewater: Characteristics and Treatment Universidad de la República, Engineering School, Chemical Engineering Institute, Forest.

14. Pearson D (1976) The Chemical Analysis of Foods. ( $7^{\text {th }}$ edn), Churchill Living stone, London.

15. Nelson D, Sommers L (1996) Total carbon, organic carbon, and organic matter. 961-1010. In: DL Sparks et al. (Eds.), Methods of soil analysis. Part 3. Chemical Methods. SSSA Book Series No. 5, SSSA and ASA, Madison, WI.

16. Oh S, Yoo D, Shin Y, Seo G (2005) FTIR analysis of cellulose treated with sodium hydroxide and carbón dioxide. Carbohydrate Research 340(30): 417-428.

17. Gatenholm P, Gellerstedt F (1999) Surface properties of lignocellulosic fibers bearing carboxylic groups. Cellulose 6: 103-112.

18. Gary M, Said A, Amy S (1995) Sludge Characteristics and Disposal Alternatives for the Pulp and Paper Industry. In: Proceedings of the 1995 International environmental conference; 1995 May 7-10; Atlanta, GA. Atlanta, GA: Tappi Press: pp. 269-279.

\section{Your next submission with Juniper Publishers} will reach you the below assets

- Quality Editorial service

- Swift Peer Review

- Reprints availability

- E-prints Service

- Manuscript Podcast for convenient understanding

- Global attainment for your research

- Manuscript accessibility in different formats

( Pdf, E-pub, Full Text, Audio)

- Unceasing customer service

Track the below URL for one-step submission https://juniperpublishers.com/online-submission.php 